\title{
Kloning Gen Melanoma Antigen 1 (Mage-1) dari Jaringan Testis untuk Mendapatkan Plasmid Rekombinan Mage-1
}

\author{
Gondo Mastutik, ${ }^{1}$ Reny I'tishom, ${ }^{2}$ Sunaryo Hardjowijoto, ${ }^{3}$ Suhartono Taat Putra ${ }^{1}$ \\ ${ }^{1}$ Departemen Patologi Anatomi Fakultas Kedokteran Universitas Airlangga, ${ }^{2}$ Departemen Biologi Kedokteran \\ Fakultas Kedokteran Universitas Airlangga, ${ }^{3}$ Departemen Urologi Fakultas Kedokteran Universitas Airlangga
}

\begin{abstract}
Abstrak
Gen Melanoma antigen-1 (Mage-1) diekspresikan oleh sel spermatogonia jaringan testis normal dan diekspresikan 60-80\% oleh liver penderita karsinoma hepatoseluler (KH). Ekspresi Mage-1 merupakan penanda untuk diagnosis KH serta prediktor kanker lambung dan kolorektal. Isolasi messenger ribonucleid acid (mRNA) Mage-1 dari jaringan liver penderita KH sulit dilakukan sehingga dilakukan isolasi mRNA Mage-1 dari jaringan yang mengekspresikan Mage-1, yaitu jaringan testis normal. Penelitian ini merupakan penelitian eksploratif yang dilakukan di Lembaga Penyakit Tropis Universitas Airlangga, Agustus 2006-Agustus 2008. Tujuan untuk mengkloning seluruh area koding gen Mage-1 dari jaringan testis pada vektor dan mendapatkan plamid rekombinan Mage-1. Isolasi seluruh area koding gen Mage-1 dilakukan dengan teknik semi-nested polymerase chain reaction (PCR). Seluruh area koding gen Mage-1 diisolasi, kemudian dikloningkan ke plasmid pET101/DTOPO dan ditransformasikan ke Escherichia coli (E. coli) Top10 untuk mendapatkan plasmid rekombinan Mage-1. Panjang pET101/D-TOPO adalah 5.753 bp dan area koding gen penyandi Mage-1 927 bp sehingga total panjang plasmid rekombinan 6.680 bp (5.753+927). Hasil analisis restriksi dengan EcoRV menunjukkan pita 4.230 dan $2.450(4.230+2.450=6.680)$. Analisis sekuens gen Mage-1 dari testis mempunyai homologi $100 \%$ dengan sekuens M77481 serta NM_004988, dan 99\% dengan BC01755. Simpulan, berdasarkan hasil analisis restriksi dan sekuens maka diperoleh plasmid rekombinan pETGM/MAGE1-Testis yang mengandung seluruh area koding gen Mage-1 dan dapat digunakan untuk pengembangan kit diagnostik karsinoma hepatoseluler. [MKB. 2015;47(4):199-206]
\end{abstract}

Kata kunci: Jaringan testis, karsinoma hepatoseluler, kloning, melanoma antigen-1, pET101/D-TOPO

\section{Cloning of Melanoma Antigen 1 (Mage-1) Gene from Testicular Tissue to Obtain the Recombinant Plasmid Mage-1}

\begin{abstract}
Melanoma antigen-1 (Mage-1) is expressed by spermatogonia cells of normal testicular tissue and $60-80 \%$ is expressed by the liver of hepatocellular carcinoma (HC) patients. Mage-1 expression is a marker for diagnosing $\mathrm{HC}$ and predicting gastric and colorectal cancers. Isolation of messenger ribonucleid acid (mRNA) Mage-1 from the liver tissue of HC patients is difficult; therefore, Mage- 1 mRNA isolates can be obtained from tissues that express Mage- 1 such as normal testicular tissues. This is an explorative research that was conducted at the Institute of Tropical Diseases of Airlangga University during August 2006-August 2008. The aim was to clone the coding sequence of Mage-1 gene from testicular tissues into a vector and to get recombinant plasmid Mage1. Isolation of the full-length Mage-1 was performed using semi-nested polymerase chain reaction (PCR) which was then cloned into plasmid pET101/D-TOPO and transformed into Escherichia coli (E. coli) Top10 to get recombinant plasmid Mage-1. The length of pET101/D-TOPO was 5,753 bp and Mage-1 was $927 \mathrm{bp}$. The length of recombinant plasmid was 6,680 bp (5,753+927). Restriction analysis using EcoRV showed 4,230 and 2,450 bp bands $(4,230+2,450=6,680)$. Sequence analyses showed that Mage- 1 was $100 \%$ homologous with M77481 and NM_004988, 99\% homologous with BC01755. In conclusion, according to the results of the restriction and sequences analysis, the recombinant plasmid pETGM/MAGE1-Testis contains the full length coding region of Mage-1 and is useful for developing the hepatocellular carcinoma diagnostic kits. [MKB. 2015;47(4):199-206]
\end{abstract}

Key words: Cloning, hepatocellular carcinoma, melanoma antigen-1, pET101/D-TOPO, testicular tissue

Korespondensi: Dr. Gondo Mastutik drh., M.Kes, Departmen Patologi Anatomi, Fakultas Kedokteran Universitas Airlangga, Jalan Prof .Dr. Moestopo No. 47 Surabaya 60131, Telepon (031) 5020251 ext 151, Fax. (031) 5026333, mobile 081231071818, e-mail gondomastutik@gmail.com 


\section{Pendahuluan}

Gen melanoma antigen (Mage) termasuk gen kanker testis dan diberi nama demikian karena hanya diekspresikan pada sel kanker dan testis normal sehingga disebut juga dengan istilah gen kanker-testis untuk gen pengkode dan antigen kanker-testis untuk antigen. Gen ini pertama kali diisolasi dari jaringan kulit penderita melanoma dan kemudian dikenal sebagai gen Mage. Gen Mage-1 (disebut juga gen Mage-A) termasuk antigen kanker yang dikode oleh keluarga gen Mage. Gen Mage-1 terletak di kromosom Xq28 dan diekspresikan pada sel spermatogonia di jaringan testis normal. ${ }^{1,2}$ Gen Mage-1 tersebut diekspresikan terhadap jaringan liver penderita karsinoma hepatoseluler (KH) ukurannya $<2 \mathrm{~cm}$, pada kadar alpha feto protein (AFP) normal atau abnormal, dan tidak diekspresikan pada jaringan liver nontumor dan juga jaringan liver yang terinfeksi virus hepatitis. Ekspresi Mage-1 pada jaringan liver penderita KH berhubungan dengan penyimpangan hipometilasi genom termasuk pada domain promoter Mage- $1^{3}$ sudah terjadi sejak awal transformasi malignan dan juga terus berlanjut selama progresi menjadi karsinoma hepatoseluler ${ }^{4}$ sehingga ekspresi messenger ribonucleid acid (mRNA) atau protein Mage-1 pada jaringan liver penderita $(\mathrm{KH})$ menunjukkan transformasi sel ke arah keganasan.

Ekspresi gen Mage-1 merupakan penanda untuk diagnosis $\mathrm{KH}^{5}$ dan untuk memprediksi terdapat kanker lambung dan kolorektal. ${ }^{6}$ Hal tersebut memperlihatkan bahwa protein Mage-1 tersebut dapat dipergunakan sebagai biomaterial sebagai pengembangan diagnosis karsinoma hepatoseluler. Isolasi mRNA Mage-1 dari jaringan liver penderita karsinoma hepatoseluler sulit dilakukan. Biopsi terbuka dan reseksi jaringan liver pada penderita karsinoma hepatoseluler jarang sekali dilakukan karena risiko perdarahan yang sulit dikendalikan sehingga sulit untuk melakukan isolasi mRNA Mage-1 jaringan kanker. Pengambilan jaringan dengan teknik fine needle aspiration biopsy (FNAB) ini mempergunakan jarum berukuran kecil (22G atau 24G) yang dipandu dengan tuntunan computer tomography scan (CT-scan). Namun, karena jumlah sel yang dapat diaspirasi dengan teknik FNAB sangat sedikit sehingga isolasi mRNA Mage-1 dari hasil FNAB jaringan liver pada penderita KH juga sulit untuk dilakukan. Selain itu, penanganan sampel ribonuccleid acid (RNA) lebih sulit dilakukan karena RNA mudah didegradasi oleh RNAase. Oleh karena itu, perlu dilakukan isolasi mRNA Mage-1 dari sampel mengekspresikan Mage-1, yaitu jaringan testis normal.

Penelitian ini adalah penelitian eksploratif yang bertujuan mengkloning area koding gen Mage-1 dari jaringan testis pada vektor serta untuk mendapatkan plamid rekombinan Mage-1.

\section{Metode}

Penelitian ini merupakan penelitian eksploratif laboratorium yang dilaksanakan di Lembaga Penyakit Tropis Universitas Airlangga pada bulan Agustus 2006-Agustus 2008. Sampel diperoleh dari jaringan testis penderita kanker prostat yang berusia $>70$ tahun dan yang mendapatkan terapi orkidektomi. Sebelum dilakukan isolasi seluruh area koding gen Mage-1, terlebih dahulu dilakukan identifikasi mRNA Mage-1 memakai metode yang sudah dilaporkan sebelumnya. ${ }^{7}$ Primer yang dipergunakan untuk identifikasi meliputi area exon 1, exon 2, dan sebagian exon 3 karena area ini merupakan area yang paling conserve untuk gen Mage-1.

Isolasi pada seluruh area koding gen Mage-1 dilakukan dengan teknik semi nested polymerase chain reaction (PCR). ${ }^{8}$ Hasil PCR yang pertama, yaitu meliputi area gen Mage-1 exon 1, 2, dan 3 dengan total produk $1.105 \mathrm{bp}$, lalu dilakukan PCR kedua dengan menggunakan template hasil PCR pertama. Hasil yang diperoleh dari PCR kedua ini, yaitu seluruh area koding gen Mage-1 yang terletak pada exon 3 dengan produk sekitar 931 bp. Plasmid yang dipergunakan yaitu pET101/DTOPO. Hasil yang diharapkan dari penelitian ini, yaitu mendapatkan plasmid rekombinan Mage1. Primer yang dipergunakan untuk mengisolasi pada seluruh area koding gen Mage-1 adalah GMTOPOF CACCATGTCTCTTGAGCAGAGGAGTC dan GMTOPOR GCTTTGAGAG AGGAGGAAGAGGGAGTC yang menghasilkan 931bp. Kondisi PCR, yaitu predenaturation pada $95^{\circ} \mathrm{C}$ selama 5 menit, denaturation pada $95^{\circ} \mathrm{C}$ selama 1 menit, annealing pada $60^{\circ} \mathrm{C} 1$ menit, extension pada $72^{\circ} \mathrm{C} 1$ menit, 35 siklus dan final extension pada $72^{\circ} \mathrm{C}$ selama 10 menit. Hasil PCR itu dianalisis dengan gel elektroforesis pada gel agarose $2 \%$ yang mengandung ethidium bromide, setelah itu divisualisasikan mempergunakan ultraviolet (UV) transluminator. Produk PCR kemudian dipurifikasi untuk persiapan kloning.

Hasil purifikasi produk PCR dikloningkan pada vektor ekspresi pET 101/D-TOPO yang memiliki penanda histidin untuk memudahkan purifikasi protein rekombinan. Campuran reaksi, yaitu 1 $\mu \mathrm{L}$ bufer, $1,5 \mu \mathrm{L}$ produk PCR, dan $0,5 \mu \mathrm{L}$ vektor yang dicampur dengan pipet. Total volume $3 \mu \mathrm{L}$. 
Campuran reaksi diinkubasi dalam es selama 5 menit, kemudian langsung ditransformasikan ke Escherichia coli (E. coli) Top10.

E. coli Top10 disiapkan sebagai sel kompeten dengan memakai kalsium klorida $\left(\mathrm{CaCl}_{2}\right)$. Vektor yang mengandung deoxyribonucleic acid (DNA) target hasil kloning ditransfromasi ke E. coli Top10 dengan cara mencampurkan campuran reaksi hasil kloning dengan $200 \mu \mathrm{L}$ sel kompeten E. coli Top10 secara hati-hati dan juga dibiarkan dalam es selama 30 menit, kemudian dilakukan heat shock. Tube yang berisi hasil kloning dan sel kompeten dimasukkan ke dalam water bath $42^{\circ} \mathrm{C}$ selama 45 detik, kemudian direndam dalam es selama 5 menit. Setelah itu ditambahkan $100 \mu \mathrm{L}$ media super optimal catabolite (SOC) suhu kamar dan diinkubasi selama 60 menit pada water bath suhu $37^{\circ} \mathrm{C}$, kemudian disebar pada media luria broth (LB) padat yang mengandung $100 \mu \mathrm{g} / \mathrm{mL}$ ampisilin dan selanjutnya dikultivikasi dalam inkubator suhu $37^{\circ} \mathrm{C}$ selama 16 jam.

Sel transforman yang mengandung DNA target diinokulasi pada $10 \mathrm{~mL}$ media LB cair yang mengandung ampisilin $100 \mathrm{mg} / \mathrm{mL}$. Kultur diinokulasi semalam (overnight) dalam shaker incubator pada $37^{\circ} \mathrm{C}$ dengan shaker $200 \mathrm{rpm}$. Isolasi plasmid dilakukan dari hasil kultivikasi memakai high speed plasmid mini kit (Geneaid) seperti petunjuk buku manual.

Analisis plasmid rekombinan pETGM/Mage 1-testis dilakukan dengan cara analisis sekuens nukleotida dari DNA target yang terdapat pada plasmid untuk mengetahui keberhasilan kloning. Analisis ini meliputi uji restriksi dengan enzim restriksi dan sekuensing untuk uji homologi.

\section{Hasil}

Isolasi seluruh area koding gen Mage-1 dilakukan dengan teknik semi nested PCR. Primer yang dipergunakan untuk mengisolasi seluruh area koding gen Mage-1, yaitu GMTOPOF CACCATGTCTCTTGAGCAGAGGAGTC dan juga GMTOPOR GCTTTGAGAGAGGAGGAAGA-GGGAGTC yang menghasilkan produk sekitar 931 bp (Gambar 1).

Produk PCR dipurifikasi terlebih dahulu untuk persiapan kloning dan sekuensing. Purifikasi ini dilakukan untuk menghilangkan sisa primer dan pengotor lain seperti garam, sisa enzim, agarosa, pewarna, ethidium bromida, mineral oil, dan juga deterjen yang tidak terikat pada membran silika gel. Penambahan bufer PE yang mengandung etanol membuat pengotor akan mengalir keluar dari matriks kolom melalui tahapan sentrifugasi

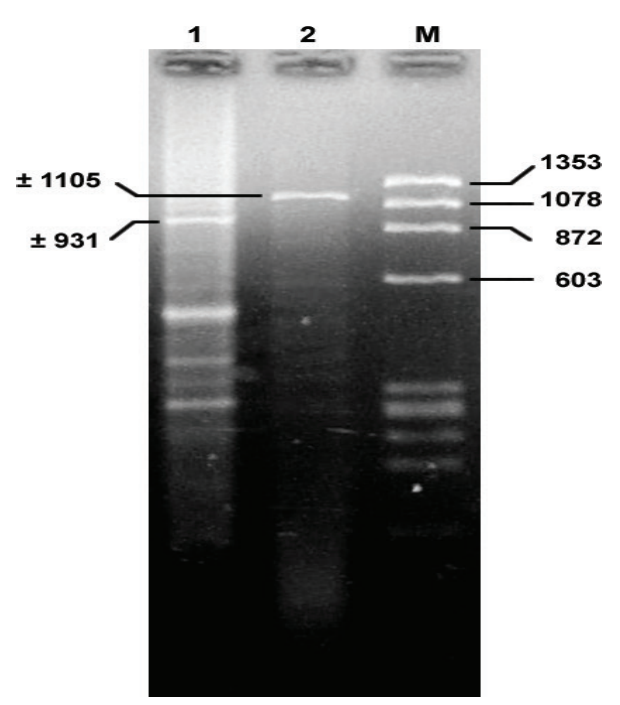

Gambar 1 Hasil Elektroforesis Produk PCR dengan Primer GMTOPOF dan GMTOPOR dari Sampel Jaringan Testis Normal. ${ }^{8} 1=$ produk PCR second round ( $\pm 931 \mathrm{bp}), 2=$ produk $\mathrm{PCR}$ first round $( \pm 1.105 \mathrm{bp}), \mathrm{M}=$ Marker $1 \times 174$ RF DNA /Hae III fragments

dan tidak terikat pada membran silika. Produk PCR yang terikat pada membran dielusi dengan penambahan bufer elusi. Hasil elusi tersebut siap digunakan untuk sekuensing dan kloning.

Produk PCR atau DNA target yang sudah dipurifikasi kemudian diinsersikan ke plasmid. Plasmid yang dipergunakan, yaitu pET101/DTOPO secara langsung tanpa melalui restriksi karena vektor sudah didesain ialah untuk direct cloning. Hasil insersi itu ditransformasikan ke dalam E. coli Top10, kemudian dikulturkan pada media LB mengandung ampisilin $(100 \mu \mathrm{g} / \mathrm{mL})$.

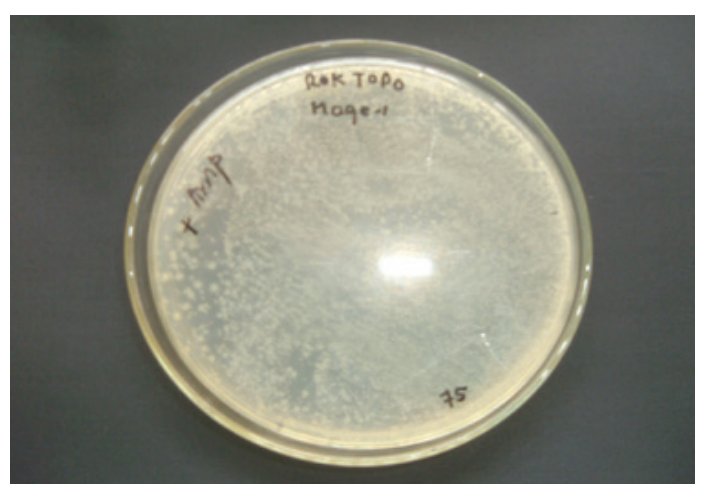

Gambar 2 Hasil Kultivasi Sel Transforman E. coli Top10 yang Mengandung Plasmid Rekombinan 


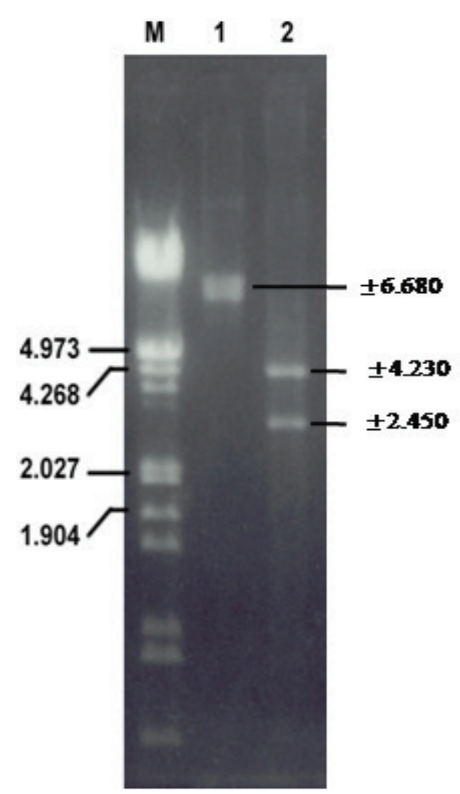

Gambar 3 Hasil Restriksi Plasmid Rekombinan Menggunakan EcoRV dari Sel Transforman E. coli Top10. M=marker DNA $\lambda$ yang dipotong dengan enzim HindIII dan EcoRI, 1=plasmid rekombinan, $2=$ hasil restriksi plasmid rekombinan dengan $E c o R V$

E. coli Top10 merupakan mikroorganisme yang sensitif terhadap antibiotik sehingga $E$. coli Top10 yang dapat tumbuh dalam media tersebut adalah sel transforman E. coli Top10 yang telah mengandung plasmid rekombinan (Gambar 2).

Analisis plasmid rekombinan itu dilakukan mempergunakan analisis restriksi EcoRV dan analisis sekuens nukleotida. Analisis restriksi menggunakan enzim EcoRV dilakukan dari hasil isolasi plasmid rekombinan yang ditransformasi ke sel kompeten E. coli Top10 dan dikultivikasi pada media LB cair yang mengandung ampisilin. Hasil restriksi plasmid rekombinan kemudian dielektroforesis dan divisualisasikan dengan UV transluminator (Gambar 3).

Sekuensing plasmid rekombinan penelitian ini mempergunakan DNA sequencer ABI PRISM 310 dengan mempergunakan big dye terminator sequencing kit (Applied biosystems). Primer yang dipergunakan adalah primer forward $\mathrm{T} 7$ 5'-TAATACGACTCACTATAGGG-3' dan juga primer reverse 5'-TAGTTATTGCTCA GCGGTGG-3'. Analisis sekuens gen Mage-1 dari testis memiliki homologi 100\% dengan sekuens M77481 dan NM_004988, dan 99\% dengan BC01755. ${ }^{8}$ Hasil sekuensing menunjukkan bahwa gen penyandi Mage-1 dari jaringan testis normal terdiri atas 927 nukleotida yang mengkode 309 asam amino termasuk start codon (Gambar 4).

Berdasarkan hasil analisis restriksi dan juga sekuensing maka diperoleh plasmid rekombinan yang mengandung seluruh wilayah koding gen Mage-1. Plasmid rekombinan tersebut diberi nama sesuai dengan nama plasmid yang dipakai, nama peneliti, dan nama gen, serta asal sampel. Plasmid yang digunakan, yaitu pET101/D-TOPO, oleh peneliti Gondo Mastutik, gen Mage-1, dan sampel itu berasal dari jaringan testis normal sehingga plasmid rekombinan yang dihasilkan pada penelitian disebut pETGM/Mage1-testis (Gambar 5).

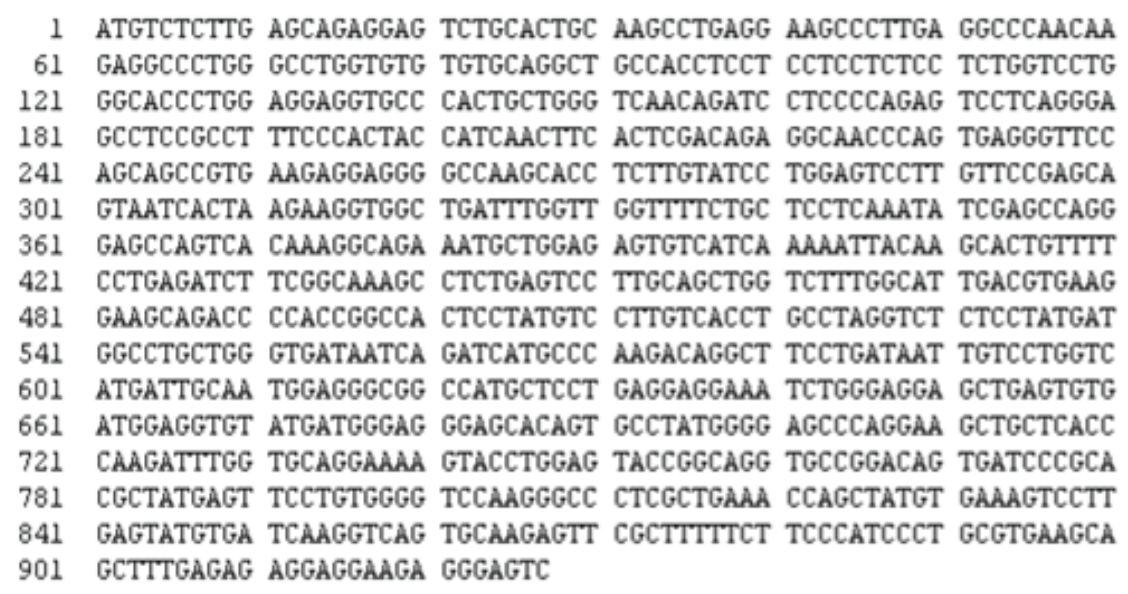

Gambar 4 Hasil Sekuensing Plasmid Rekombinan dari Sampel Jaringan Testis Normal dengan Menggunakan Primer Froward T7 dan Primer Reverse T7 


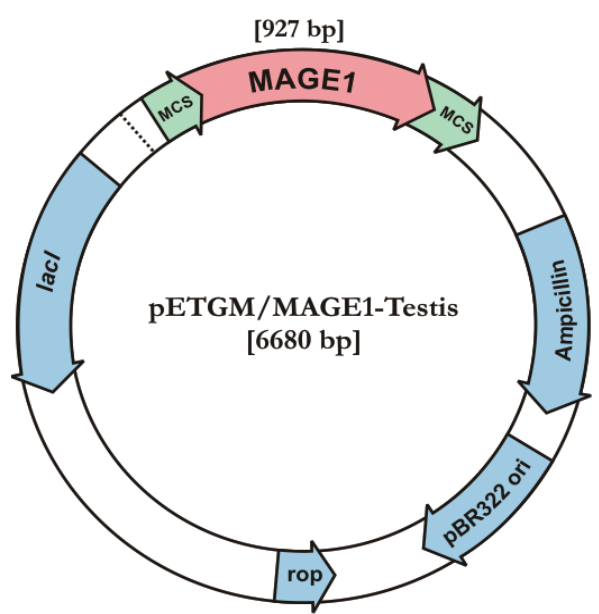

\section{Gambar 5 Peta Plasmid Rekombinan pETGM/ MAGE1-Testis dari Jaringan Testis Normal}

\section{Pembahasan}

Penelitian ini merupakan penelitian eksploratif yang memiliki tujuan mengkloning area koding gen Mage-1 dari jaringan testis pada vektor dan untuk mendapatkan plamid rekombinan Mage-1. Isolasi seluruh area koding gen Mage1 dilakukan dengan teknik semi nested PCR. Plasmid yang digunakan, yaitu pET101/D-TOPO. Hasil yang diharapkan dari penelitian ini untuk mendapatkan plasmid rekombinan Mage-1.

Primer yang dipergunakan dirancang agar mampu mengamplifikasi seluruh area koding gen penyandi Mage-1 yang disesuaikan dengan plasmid pET101/D-TOPO yang dipergunakan untuk kloning. Primer forward ditambah empat nukleotida (CACC) pada ujung 5' sebelum start codon (ATG) sebagai tempat perlekatan dengan plasmid yang memiliki overhang GTGG (komplemen CACC). Primer reverse tidak boleh mengandung sekuens stop codon (TAA, TGA, TAG) agar plasmid rekombinan yang dihasilkan mempunyai histaq yang berguna dalam proses purifikasi protein. ${ }^{9}$ Stop codon gen Mage-1, yaitu TGA sehingga sekuens TGA harus dihilangkan dari sekuens primer reverse. Sekuens primer reverse didesain agar mampu menempel pada kodon kedua terakhir sebelum TGA karena stop codon yang dipakai adalah stop codon vektor.

Hasil PCR yang pertama meliputi area gen Mage 1 exon 1, 2, dan 3 dengan total produk $1.105 \mathrm{bp}$, kemudian dilakukan PCR kedua dengan mempergunakan template hasil PCR pertama. Primer yang digunakan untuk PCR kedua, yaitu
GMTOPOF dan GMTOPOR yang menghasilkan produk sekitar $931 \mathrm{bp}$ (Gambar 1).

Reagen PCR pada penelitian ini ialah High fidelity platinum Taq DNA polymerase. ${ }^{10}$ Panjang DNA target untuk amplifikasi seluruh area koding gen $M A G E-1$, yaitu 1.105 bp sehingga memerlukan penggunaan Taq yang memiliki fidelitas tinggi. Produk PCR ini kemudian dipurifikasi untuk dilakukan kloning ke vektor pET101/D-TOPO. Tujuan purifikasi ialah mendapatkan DNA murni dengan menghilangkan sisa primer dan pengotor lain seperti garam-garam, sisa enzim, agarosa, pewarna, etidium bromida, mineral oil, dan juga deterjen dari produk PCR. Purifikasi dilakukan menggunakan Gel Extraction Kit (Qiagen).

Produk PCR yang telah dipurifikasi kemudian diinsersikan ke vektor pET101/D-TOPO. Vektor yang digunakan yaitu pET101/D-TOPO dengan ukuran 5.753 bp serta tersedia dalam bentuk linier sehingga proses insersi dapat langsung dilakukan (direct cloning) tanpa terlebih dahulu melakukan restriksi plasmid, seperti pada penggunaan plasmid berbentuk sirkuler. Vektor pET101/D-TOPO mempunyai promotor T7lac untuk mengendalikan ekspresi dari gen yang diinginkan dan lac operator yang terletak pada down stream dari T7 promotor. Lac operator merupakan binding site untuk lac represor (lacl gene) yang berfungsi untuk menekan basal transcription plasmid di dalam E. coli BL21star.

E. coli Top10 dipergunakan untuk propagasi (memperbanyak atau amplifikasi molekul DNA target) dan juga maintenance (mempertahankan sekuens DNA target) serta untuk karakterisasi DNA plasmid rekombinan. Karakterisasi ini diperlukanuntuk dapat mengetahui keberhasilan kloning dengan cara melakukan analisis struktur yang meliputi analisis restriksi dan sekuensing. E. coli Top10 tidak mengandung gen T7 RNA polymerase sehingga DNA target tidak mampu diekspresikan menjadi protein dan kestabilan sekuens DNA plasmid rekombinan terjaga.

Plasmid rekombinan lalu ditransformasi pada E. coli Top10. E. coli disiapkan untuk menerima plasmid dengan menambahkan $\mathrm{CaCl}_{2}$ sebelum melakukan transformasi pada E. coli Top10. Fungsi penambahan $\mathrm{CaCl}_{2}$ untuk melemahkan dinding sel E. coli sehingga dapat mempermudah plasmid rekombinan masuk ke dalam E. coli pada saat proses heat shock. E. coli yang telah siap untuk digunakan transformasi disebut sel kompeten.

Plasmid rekombinan pETGM/Mage1-testis siap ditransformasi ke dalam sel kompeten E. coli Top10. Sel kompeten dikeluarkan dari deep frezer $-80^{\circ} \mathrm{C}$ dan segera dimasukkan ke es serut agar 
proses thawing berjalan lambat. Sel kompeten dicampur dengan plasmid rekombinan secara perlahan kemudian tube dimasukkan es serut lagi selama 30 menit agar plasmid rekombinan bercampur dan menyatu dengan sel kompeten. Heat shock dilakukan dalam water bath $42^{\circ} \mathrm{C}$ selama 45 detik untuk membuat kejutan pada sel kompeten sehingga plasmid rekombinan masuk melalui membran sel ke dalam sitoplasma E. coli. Tube yang mengandung plasmid rekombinan segera dimasukkan/direndam ke dalam es serut agar pori-pori yang terbentuk di membran $E$. coli segera menutup kembali sehingga plasmid yang sudah tranformasi ke E. coli tidak keluar lagi. Kemudian ditambahkan media SOC yang kaya nutrisi untuk pertumbuhan E. coli. Hasil transformasi kemudian dikultur pada media seleksi, yaitu media LB agar yang mengandung ampisilin pada inkubator $37^{\circ} \mathrm{C}$ selama $16-18$ jam.

Seleksi dilakukan dengan memberi antibiotik ampisilin. Plasmid didesain mengandung gen resisten ampisilin, yaitu gen $\beta$ lactamase. Protein $\beta$ laktamase disekresikan ke dalam media, lalu menghidrolisis ampisilin sehingga ampisilin itu tidak aktif. Sel transforman yang mengandung plasmid rekombinan akan tumbuh subur pada media seleksi yang mengandung ampisilin, sedangkan E. coli itu sendiri peka terhadap ampisilin sehingga $E$. coli yang tidak mengandung plasmid rekombinan tidak dapat tumbuh pada media seleksi. Kontrol negatif yang digunakan adalah $E$. coli yang sama, tetapi ditransformasi dengan destilated water yang tidak mengandung plasmid rekombinan. Hasil kontrol negatif itu menunjukkan bahwa E. coli tidak tumbuh pada media yang mengandung ampisilin. Keadaan ini menunjukkan bahwa E. coli yang tumbuh pada media LB yang mengandung ampisilin tersebut memang benar $E$. coli yang mengandung plasmid rekombinan.

Apabila sel transforman tumbuh pada media selektif yang mengandung ampisilin diharapkan proses kloning berhasil gen Mage-1 dari jaringan testis normal telah terinsersi pada pET101/DTOPO yang ditunjukkan dengan pertumbuhan koloni bakteri pada media seleksi (Gambar 2). Sel hospes akan memperbanyak diri dengan cara pembelahan yang diikuti oleh plasmid sehingga didapatkan klon sel transforman dalam jumlah banyak yang mengandung plasmid beserta molekul DNA rekombinan gen Mage-1.

Analisis plasmid rekombinan merupakan cara untuk mengetahui keberhasilan kloning DNA target pada plasmid yang meliputi uji restriksi dengan enzim restriksi EcoRV dan sekuensing dengan analisis homologi. Analisis plasmid rekombinan dilakukan pada hasil isolasi plasmid rekombinan. Tujuan isolasi plasmid adalah memisahkan DNA plasmid rekombinan yang mengandung DNA target dari DNA kromosom bakteri. Isolasi DNA plasmid pada penelitian ini menggunakan kit high speed plamsid mini kit (Geneaid).

Analisis restriksi menggunakan enzim EcoRV yang termasuk enzim endonuklease tipe II dari Escherichia coli. Nama lainnya adalah Eco32I. EcoRV akan memotong restriction site GATATC secara blunt end pada TA. Panjang pET101/DTOPO yaitu $5.753 \mathrm{bp}$, setelah dilakukan insersi area koding gen penyandi Mage-1 yang terdiri atas 927 bp (karena dikurangi 3bp stop codon) sehingga total panjang DNA rekombinan pETGM/ Mage1-testis adalah 6.680 bp $(5.753+927)$ (Gambar 5).EcoRV memotong pada nukleotida ke 545 dan 4.775. Hasil restriksi EcoRV, adalah band dengan ukuran 4.230 dan $2.450(4.230+2.450=$ 6.680) (Gambar 4).

Sekuensing dilakukan menggunakan primer T7 foward serta reverse. Primer T7 forward menempel pada nukleotida 109-128 dan juga T7 reverse menempel pada nukleotida 1.381-1.402 setelah ditambah gen penyandi Mage-1. Primer GMTOPOF menempel pada nukleotida 302 yang terletak setelah sekuens promotor T7. Hal ini penting karena aktivasi transkripsi pada plasmid menggunakan promotor T7 sehingga gen Mage1 dapat ditranskripsi pada plasmid. Stop codon yang digunakan untuk menghentikan transkripsi adalah stop codon vektor yang terletak setelah penanda histidin (6x histidin). Penanda histidin ini dipakai untuk memudahkan purifikasi protein rekombinan menggunakan metode kromatografi afinitas nickel nitrilotriacetic acid (Ni-NTA) yang mampu mengikat histidin pada kolom nikel. Dengan demikian protein yang diperoleh tidak mengandung protein sel inang sehingga murni hanya protein target yang dimaksud di dalam penelitian.

Hasil sekuensing ini memperlihatkan bahwa gen penyandi Mage-1 dari jaringan testis normal terdiri atas 927 nukleotida yang mengkode 309 asam amino termasuk start dan tanpa stop codon. Hal ini sesuai data gen Mage-1 yang terdapat di GeneBank, yaitu gen Mage-1 terdiri atas 3 ekson dan 2 intron. mRNA Mage-1 terdiri atas 1.722 nukleotida, area koding terletak pada ekson 3 pada nukleotida 188-1.117 (927 nukleotida termasuk start dan tanpa stop codon). Setelah stop codon (nukleotida 1.117) masih terdapat beberapa nukleotida dan poly tail A.

Sekuens gen Mage-1 dari jaringan testis yang 
normal mempunyai homologi $100 \%$ dengan sekuens M77481 dan juga NM_004988 yang berasal dari jaringan melanoma kulit dan 99\% dengan sekuens AY148486 yang berasal dari liver penderita karsinoma hepatoseluler dan BC017555 yang berasal dari jaringan melanoma kulit. Hal ini menunjukkan bahwa sekuens gen Mage-1 pada penelitian ini dengan sekuens yang ada di Gen Bank dari jaringan kulit melanoma (M77481 dan juga NM_004988) adalah sama, tetapi mempunyai satu perbedaan nukleotida dari jaringan kulit melanoma (BC017555) dan sekuens dari liver penderita karsinoma hepatoseluler (AY148486). Satu nukleotida yang berbeda ini merupakan polymorphisme ${ }^{11}$ tiga tipe nukleotida gen Mage-1 dari jaringan liver penderita karsinoma hepatoseluler dengan kode nomer akses AY148486 dan AF463515, serta satu sekuens M77481 yang mempunyai sekuens sama. ${ }^{8}$

Hasil penelitian ini memperlihatkan bahwa sekuens gen Mage-1 dari testis homolog dengan sekuens Mage-1 dari jaringan liver penderita karsinoma hepatoseluler. Persamaan sekuens ini memperlihatkan bahwa protein Mage-1 dari testis sama dengan protein Mage-1 dari liver penderita karsinoma hepatoseluler. Hasil isolasi mRNA Mage-1 dari testis dapat dipergunakan sebagai pengganti mRNA Mage-1 dari jaringan liver penderita karsinoma hepatoseluler. Isolasi mRNA Mage-1 dari jaringan liver penderita karsinoma hepatoseluler sulit dilakukan karena risiko perdarahan yang sulit dihentikan sehingga pembedahan pada liver penderita karsinoma hepatoseluler jarang dilakukan. Diagnosis pasien dilakukan memakai teknik FNAB dan tuntunan radiologi untuk mendapatkan hapatosit yang telah berubah menjadi sel kanker. Hasil FNAB ini sangat sedikit, hanya sekitar 6 slide sehingga diagnosis yang dibuat harus benar. Jika terdapat kasus sulit untuk membedakan sel jinak dengan ganas maka diperlukan kit diagnostik yang dapat digunakan untuk melakukan diagnosis.

Plasmid rekombinan pETGM/Mage1-testis dari sampel jaringan testis selanjutnya digunakan untuk penelitianlanjutan, yaitu mengekspresikan plasmid pada E. coli untuk menghasilkan protein rekombinan gen Mage-1. Protein rekombinan Mage-1 yang disuntikkan ke hewan coba untuk menghasilkan antibodi anti Mage-1 yang dapat digunakan sebagai antibodi untuk mendeteksi antigen (protein) Mage-1 itu dari jaringan liver hepatoma. Penelitian ini merupakan penelitian awal dalam proses penelitian untuk pembuatan antibodi monoklonal anti Mage-1 yaitu sebagai biomaterial sebagai pengembangan diagnosis karsinoma hepatoseluler.

Simpulan, sekuens gen Mage-1 dari testis homolog dengan sekuens Mage- 1 dari jaringan liver pada penderita karsinoma hepatoseluler. Penelitian ini menghasilkan plasmid rekombinan pETGM/Mage1-testis yang dapat dipergunakan untuk penelitian lanjutan dalam pengembangan kit diagnosis karsinoma hepatoseluler.

\section{Daftar Pustaka}

1. Caballero OL, Chen YT. Cancer/testis (CT) antigens: potential targets for immunotherapy. Cancer Sci. 2009;100(11): 2014-21.

2. Suzuki S, Sasajima K, Sato Y, Watnabe H, Matsutani T, Iida S, dkk. MAGE-A protein and MAGE-A10 gene expressions in liver metastasis in patients with stomach cancer. Br J Cancer. 2008;99(2):350-6.

3. Xiao J, Chen HS, Fei R, Cong X, Wang LP, Wang Y, dkk. Expression of MAGE-A1 mRNA is associated with gene hypomethylation in hepatocarcinoma cell lines. J Gastroenterol. 2005;40(7):716-21.

4. Calvisi DF, Ladu S, Gorden A, Farina M, Lee JS, Conner EA, dkk. Mechanistic and prognostic significance of aberrant methylation in the molecular pathogenesis of human hepatocellular carcinoma. J Clin Invest. 2007;117(9):2713-22.

5. Yang SZ, Dong JH, Li K, Zhang Y, Zhu J. Detection of AFPmRNA and Melanoma Antigen Gene-1 mRNA as markers of disseminated hepatocelluler carcinoma cells in blood, Hepatobilliary Pancreat Dis int. 2005;4(2):227-32.

6. Lee TB, Lim SC, Moon YS, Choi CH. Melanoma antigen gene family as a molecular marker of gastric and colorectal cancers. Oncol Rep. 2013;30(1):234-8.

7. Mastutik G, Hardjowijoto S, Lunardi JH, Soemarsono T., Puspaningsih NNT, Budy TI, dkk. Mage- 1 cDNA isolation from testis with RT PCR. Folia Medica Indonesiana. 2007;43(4):195-200.

8. Mastutik G, Hardjowijoto S, Lunardi JH, Puspaningsih NNT, Soetjipto, Kusumobroto HO, dkk. Molecular analysis of the coding sequence of Mage-1 gene from hepatocelular carcinoma patient and testis. Folia Medica Indonesiana. 2008;44(4):224-32.

9. Invitrogen. Champion pET Directional TOPO Expression Kits Version II. 2006. 25-0400.

10. Invitrogen. Platinum taq DNA polymerase 
Gondo M.: Kloning Gen Melanoma Antigen 1 (Mage-1) dari Jaringan Testis untuk Mendapatkan Plasmid Rekombinan Mage-1

high fidelity, manual book. 2006. [diunduh Januari 2015] Tersedia dari: http://www. invitrogen.com.

11. Wang LP, Chen HS, Mei MH, Qin LL, Cong $\mathrm{X}$, Fei R, dkk. The genetic polymorphism of melanoma-associated antigen 1 in chinese normal donors and hepatoma patients. Zhonghua Gan Zang Bing Za Zhi. 2004;12 (3):151-5. 